\title{
ANTIOXIDANT ACTIVITY OF LICHEN CETRARIA ACULEATA
}

\section{AUTHORS}

Tomović J. ${ }^{1}$, Rančić A. ${ }^{1}$, Vasiljević $P .^{2}$, Mašković P. ${ }^{3}$, Živanović S. ${ }^{4}$, Manojlović N. ${ }^{1}$, Sovrlić M. ${ }^{1}$

${ }^{1}$ Faculty of Medical Sciences, University of Kragujevac, Kragujevac, Serbia

${ }^{2}$ Faculty of Science, University of Niš, Niš, Serbia

${ }^{3}$ Faculty of Agriculture, University of Kragujevac, Čačak, Serbia

${ }^{4}$ Faculty of Medicine, University of Niš, Niš, Serbia

\section{KORESPONDENT}

JOVICA TOMOVIĆ

Faculty of Medical Sciences, University of Kragujevac, Kragujevac, Serbia

$\triangle$ jovicatomovic2011@gmail.com

\section{SUMMARY}

The aim of the present study is to investigate the antioxidant properties of the lichen Cetraria aculeata. Antioxidant activity of the methanol and ethyl acetate extracts of lichen was tested by different methods including determination of total phenolics content, determination of total antioxidant capacity, DPPH free radical scavenging activity, inhibitory activity towards lipid peroxidation, ferrous ion chelating ability and hydroxyl radical scavenging activity. The extracts of the lichen $C$. aculeata showed significant antioxidant activity. The methanol extract showed higher values for total phenolics and total antioxidant capacity compared to the ethyl acetate extract, while the ethyl acetate extract demonstrated better results for DPPH radical scavenging, inhibitory activity towards lipid peroxidation, chelating ability and hydroxyl radical scavenging than the methanol extract. This is the first report of the antioxidant properties of Cetraria aculeata growing in Serbia. The results of antioxidant activity indicate the application of this lichen as source of natural antioxidants that could be used as a possible food supplement, in the pharmaceutical industry and in the treatment of various diseases.

Keywords: ROS, antioxidant activity, lichen, Cetraria aculeata.

\section{INTRODUCTION}

Active oxygen exists in different forms, such as superoxide anion radicals $\left(\mathrm{O}_{2} \bullet-\right)$, hydrogen peroxide $\left(\mathrm{H}_{2} \mathrm{O}_{2}\right)$, hydroxyl radicals $(\mathrm{OH} \bullet)$ and singlet oxygen $\left({ }^{1} \mathrm{O} 2\right)$. These forms of oxygen are highly reactive intermediates, and have a collective name of reactive oxygen species (ROS) $[1,2,3,4,5]$. ROS are free radicals very important for living organisms, in which are formed in different ways. In normal aerobic respiration, stimulated polymorphonuclear leukocytes and macrophages, and peroxisomes appear to be the main endogenous sources of most oxidants produced by cells. However, despite the fact that ROS are necessary for cell function, in high concentrations leads to oxidative stress and to the development a large number of diseases such as arthritis, carcinogenesis, aging. In addition to endogenous sources of free radicals, a major contribution of the accumulation of free radicals in cells are provided by exogenous sources such as ionizing radiation, tobacco smoke, certain pollutants, organic solvents and pesticides $[4,6,7$, $8,9,10]$. The above mentioned diseases and accelerated aging are the consequence of oxidative tissue damage by free radicals because of unbalanced mechanisms of antioxidant protection under the influence of endogenous and exogenous factors [11]. ROS attack unsaturated fatty acids in membrane proteins, causing lipid peroxidation, and the result is damage to membrane proteins [12]. This leads to reduced permeability of membranes, receptors and enzyme activity, and reduced activation of cells. Free radicals attack the DNA, while leading to DNA damage, resulting in mutations that cause cancer. Therefore, the prevention of many diseases are important antioxidant defense systems, including food, drugs and antioxidant enzymes $[13,14]$.

Antioxidants are compounds of natural and synthetic origin, which have the ability to inhibit or delay the process of oxidation caused by free radicals. They prevent the initiation of oxidizing chain reactions. In this way, protect the body from oxidative stress caused by free radicals $[15,16,17]$. However, despite widespread use of synthetic antioxidants, at the moment it is limited because of suspicions that they manifest toxic and carcinogenic effects such as butylated hydroxytoluene (BHT), butylated hydroxyanisole (BHA), tertbutylhydroquinone (TBHQ) and propyl gallate (PG). Because of this there is a great interest for finding natural antioxidants, which do not cause adverse effects [18, 19]. Therefore, attention will be focused to the lichen as a natural source of antioxidants due to insufficient research of their antioxidant properties.

Lichens are complex associations composed of fungi ("micobiont") and one or more algae or cianobacteria ("photobionts") living in symbiosis [20]. So far more than 20.000 known species of lichens have been determined and more than 1000 primary and secondary metabolites 
of lichens have been identified [21,22]. Secondary metabolites of lichens represent different classes of chemical compounds (dibenzofurans, depsides, depsidones, depsones, lactones, quinones, etc.), which contain in their structure a phenolic groups that have the ability to scavenge toxic free radicals. Because these metabolites exhibit strong antioxidant activity, about which are reported $[23,24,25]$. It has been found that depsidones are more efficient antioxidants than depsides [26].

Until now, the extracts of Cetraria aculeata have been explored for antimicrobial activity [27] and genotoxic/antigenotoxic and cytotoxic activities [28].

\section{STUDY OBJECTIVE}

The aim of the present study was to investigate the antioxidant properties of Cetraria aculeata in order to find an easily accessible source of natural antioxidants that could be used as a possible food supplement, in the pharmaceutical industry and in the treatment of various diseases.

\section{MATHERIAL AND METHODS}

\section{LICHEN MATERIAL}

The lichen Cetraria aculeata (Schreb.), family Parmeliaceae, was collected from Kopaonik (Ploce) in Serbia during the april 2011. Voucher specimens (9064, HMN) were deposited in the herbarium of the Department of Biology and Ecology, Faculty of Sciences and Mathematics, University of Nis.

\section{PREPARATION OF THE LICHEN EXTRACTS}

The extraction of the lichen Cetraria aculeata was performed by macerating lichen sample with separately methanol and ethyl acetate. The lichen material was dried one week at room temperature $\left(26^{\circ} \mathrm{C}\right)$, after which it was ground to a uniform powder. Then, $500 \mathrm{~g}$ dry powdered lichen material was soaked in $2000 \mathrm{~mL}$ of an appropriate solvent (methanol and ethyl acetate) at room temperature for three days. After which extracts were filtered through a Whatman no. $42(125 \mathrm{~mm})$ filter paper and concentrated in a rotary evaporator. In this way, both extracts has been prepared.

\section{DETERMINATION OF THE TOTAL PHENOLICS}

Determination of total phenolics content was performed using the Folin-Ciocalteu method [29]. The lichen extract was diluted to the concentration of $1 \mathrm{mg} / \mathrm{mL}$, and aliquots of $0.5 \mathrm{~mL}$ were mixed with $2.5 \mathrm{~mL}$ of Folin-Ciocalteu reagent (previously diluted 10 -fold with distilled water) and $2 \mathrm{~mL}$ of $\mathrm{NaHCO} 3(7.5 \%)$. The resulting mixture was staying $15 \mathrm{~min}$ at the $45^{\circ} \mathrm{C}$, after which absorbance was measured at $765 \mathrm{~nm}$ on spectrophotometer against blank sample. Total phenolic content in the extracts were expressed in the form of gallic acid equivalents ( $\mathrm{mg}$ $\mathrm{GA} / \mathrm{g}$ extract). The values are presented as means of triplicate analyses.

\section{DETERMINATION OF TOTAL ANTIOXIDANT CAPACITY}

The total antioxidant activity of the lichen extracts was determined using the phosphomolybdenum method [30]. This test is based on the reduction of Mo (VI)-Mo (V) by the antioxidant compounds and subsequent formation of a green phosphate/Mo (V) complex at acid pH. $0.3 \mathrm{~mL}$ of sample extract was combined with $3 \mathrm{~mL}$ of reagent solution $(0.6 \mathrm{M}$ sulfuric acid, $28 \mathrm{mM}$ sodium phosphate and $4 \mathrm{mM}$ ammonium molybdate). The tubes with reaction solution were incubated at $95{ }^{\circ} \mathrm{C}$ for $90 \mathrm{~min}$. After which the absorbance of the solution was measured at $695 \mathrm{~nm}$ using spectrophotometer versus blank after cooling to room temperature. Methanol in the place of extract was used as the blank. As standard was used ascorbic acid (AA). The total antioxidant capacity was determined as milligrams of ascorbic acid per gram of the dry extract (mg AA/g extract).

\section{DETERMINATION OF DPPH FREE RADICAL SCAVENGING ACTIVITY}

The free radical scavenging activity of extracts was measured using the stable radical DPPH (1,1-diphenyl-2picryl-hydrazil) according to method [31] was adopted with suitable modifications from [32]. DPPH $(8 \mathrm{mg})$ was dissolved in $100 \mathrm{~mL}$ methanol to obtain a concentration of $80 \mu \mathrm{g} / \mathrm{mL}$. Then serial dilutions were carried out with the stock solution $(1 \mathrm{mg} / \mathrm{mL})$ of the extract. The resulting solutions $(2 \mathrm{~mL}$ each) were mixed with DPPH $(2 \mathrm{~mL})$ and allowed to stand for $30 \mathrm{~min}$ for any reaction to occur, and the absorbance was measured at $517 \mathrm{~nm}$. As reference standards were used ascorbic acid (AA), gallic acid (GA) and butylated hydroxytoluene (BHT) and dissolved in methanol were used to make the stock solution with the same concentration $(1 \mathrm{mg} / \mathrm{mL})$. Control sample was prepared containing the same volume without test compounds or reference antioxidants. Methanol $95 \%$ was used as blank. Inhibition DPPH free radical scavenging activity (\%) of lichen extract was calculated using the following equation:

$\%$ inhibition $=[(\mathrm{Ac}-\mathrm{As}) / \mathrm{Ac}] \times 100$

(1) where Ac was the absorbance of the control (containing DPPH of the stock solution and methanol), and As was the absorbance of the sample (containing sample extract solution or standard solution without DPPH of the stock solution).

Results are presented as the IC50 values (minimum concentration of the each tested sample that reduces $50 \%$ of the DPPH radical, was calculated as $\mu \mathrm{g} / \mathrm{mL}$ through sigmoidal dose-response curve).

\section{DETERMINATION OF THE INHIBITORY ACTIVITY TOWARD LIPID PEROXIDATION}

The antioxidant activity of extracts was determined using the thiocyanate method [33]. Serial dilutions were carried out with the stock solution $(1 \mathrm{mg} / \mathrm{mL})$ of the extracts, and $0.5 \mathrm{~mL}$ of each solution was added to linoleic acid emulsion $(2.5 \mathrm{~mL}, 40 \mathrm{mM}, \mathrm{pH} 7.0)$. The linoleic acid emulsion was prepared by mixing $0,2804 \mathrm{~g}$ linoleic acid, $0.2804 \mathrm{~g}$ Tween-20 as emulsifier in $50 \mathrm{~mL} 40 \mathrm{mM}$ phosphate buffer and the mixture was then homogenized. The final volume was adjusted to $5 \mathrm{~mL}$ with $40 \mathrm{mM}$ phosphate buffer, $\mathrm{pH}$ 7.0. After incubation at $37^{\circ} \mathrm{C}$ in the 
dark for 72 hours, a $0.1 \mathrm{~mL}$ aliquot of the reaction solution was mixed with $4.7 \mathrm{~mL}$ of ethanol $(75 \%), 0.1 \mathrm{~mL}$ $\mathrm{FeCl} 2(20 \mathrm{mM})$ and $0.1 \mathrm{~mL}$ ammonium thiocyanate $(30 \%)$. The absorbance of this mixture was measured at $500 \mathrm{~nm}$, after it was stirred for $3 \mathrm{~min}$. As reference compounds were used ascorbic acid, gallic acid, a-tocopherol and BHT. To eliminate the solvent effect, the control sample, which contained the same amount of solvent added to the linoleic acid emulsion in the test sample and reference compound, was used. Inhibition of linoleic acid peroxidation (\%) was calculated using following formula:

$\%$ inhibition $=[(\mathrm{Ac}-\mathrm{As}) / \mathrm{Ac}] \times 100$

(2) where Ac was the absorbance of the control and As was the absorbance of the sample.

The results of inhibitory activity towards lipid peroxidation are presented as the IC50 values.

\section{MEASUREMENT OF FERROUS ION CHELATING ABILITY}

Based by decrease in absorbance at $562 \mathrm{~nm}$ of the iron (II)- ferrozine complex was measured by ferrous ion chelating ability [34, 35]. One milliliter of $0.125 \mathrm{mM}$ FeSO4 was added to $1.0 \mathrm{~mL}$ sample (with different dilutions), followed by $1.0 \mathrm{~mL}$ of $0.3125 \mathrm{mM}$ ferrozine. Before measuring the absorbance, mixture was allowed to equilibrate for $10 \mathrm{~min}$. The ability of the sample to chelate ferrous ion was calculated relative to the control (consisting of iron and ferrozine only) using the formula:

Chelating effect $(\%)=[(\mathrm{Ac}-\mathrm{As}) / \mathrm{Ac}] \times 100$

(3) where Ac was the absorbance of the control and As was the absorbance of the sample.

The results of ferrous ion chelating ability are presented as the IC50 values.

\section{DETERMINATION OF HYDROXYL RADICAL SCAVENGING ACTIVITY}

The ability of lichen Cetraria aculeata to inhibit non site-specific hydroxyl radical-mediated peroxidation was carried out according method described by [36]. The reaction mixture contained $100 \mu \mathrm{L}$ of extract dissolved in water, $500 \mu \mathrm{L}$ of $5.6 \mathrm{mM}$ 2-deoxy-D-ribose in KH2PO4$\mathrm{NaOH}$ buffer $(50 \mathrm{mM}, \mathrm{pH} 7.4), 200 \mu \mathrm{L}$ of premixed $100 \mu \mathrm{M}$ FeCl3 and $104 \mathrm{mM}$ EDTA (1:1 v/v) solution, $100 \mu \mathrm{L}$ of 1.0 $\mathrm{mM} \mathrm{H} 2 \mathrm{O} 2$ and $100 \mu \mathrm{L}$ of $1.0 \mathrm{mM}$ aqueous ascorbic acid. Tubes were vortexed and incubated at $50^{\circ} \mathrm{C}$ for $30 \mathrm{~min}$. Thereafter, $1 \mathrm{~mL}$ of $2.8 \%$ TCA and $1 \mathrm{~mL}$ of $1.0 \%$ TBA were added to each tube. The samples were vortexed and heated in a water bath at $50^{\circ} \mathrm{C}$ for $30 \mathrm{~min}$. The extent of oxidation of 2-deoxyribose was estimated from the absorbance of the solution at $532 \mathrm{~nm}$. The percentage inhibition values were calculated from the absorbance of the control (Ac) and of the sample (As), using following formula:

$\%$ inhibition $=[(\mathrm{Ac}-\mathrm{As}) / \mathrm{Ac}] \times 100$

(4) where the controls contained all the reaction reagents except the extract or positive control substance.

The results of hydroxyl radical scavenging activity are presented as the IC50 values.

\section{STATISTICAL ANALYSIS}

All computations were made by employing the statistical software (SPSS, version 11.0). Experimental results are presented as mean \pm standard deviations of three measurements. Statistical analyses were performed using Student's t-test and one way analysis of variance while the probability value of 0.05 was considered significant.

The obtained results of antioxidant activity for methanol extract of $\mathrm{C}$. aculeata were compared to the published results of the antioxidant analysis of methanol extract of T.candida [40], using the Student's t-test.

\section{RESULTS}

\section{Antioxidant activity}

Table 1 shows the results of the determination of the total phenols and antioxidant capacity of the examined C. aculeata extracts. Total phenolic contents, expressed as gallic acid equivalents were amounted to $80.8 \pm 0.79 \mathrm{mg} \mathrm{GA} / \mathrm{g}$ and $64.12 \pm 0.58 \mathrm{mg} \mathrm{GA} / \mathrm{g}$, for the methanol and ethyl acetate extracts, respectively. Results for total antioxidant capacity were amounted to $91.52 \pm 0.34 \mu \mathrm{g} \mathrm{AA} / \mathrm{g}$ and $71.5 \pm 0.29 \mu \mathrm{g} \mathrm{AA} / \mathrm{g}$, for methanol and ethyl acetate extracts, respectively.

In Table 2 are given the results of DPPH scavenging activity for the examined $C$. aculeata extracts. For the methanol extract IC50 value was $51.65 \pm 1.38 \mu \mathrm{g} / \mathrm{mL}$, while this value for the ethyl acetate extract was $41.4 \pm 0.94 \mu \mathrm{g} / \mathrm{mL}$.

The results of inhibitory activity towards lipid peroxidation (Table 2 ) of the tested extracts of C. aculeata were amounted to $45.55 \pm 0.99 \mu \mathrm{g} / \mathrm{mL}$ and $38.55 \pm 0.76$ $\mu \mathrm{g} / \mathrm{mL}$ for methanolic and ethyl acetate extracts, respectively.

In Table 2 are shown IC50 values for the metal chelating activity for the methanol and ethyl acetate extract. These values were amounted of $50.43 \pm 0.98 \mu \mathrm{g} / \mathrm{mL}$ and $40.55 \pm 0.93 \mu \mathrm{g} / \mathrm{mL}$, respectively.

The hydroxyl radical scavenging activity of the examined extracts are given in Table 2 . For the methanol extract IC50 value was $90.1 \pm 0.47 \mu \mathrm{g} / \mathrm{mL}$ while for the ethyl acetate extract this value was $79.4 \pm 0.65 \mu \mathrm{g} / \mathrm{mL}$.

\section{DISCUSSION}

Until now, many researchers investigated the antioxidant properties of many species of lichens and some of them have very good antioxidant activity [37, 38, 39, 40]. Secondary metabolites that have been identified from various species of lichen extracts manifested high antioxidant activity [23, 24, 25].

Some metabolites of lichens in their structure contain phenolic groups which are considered to be a key element for the antioxidative efficiency [41]. Protolichesterinic acid (aliphatic a- methylene- $y$-lactone) is the active substance which has been identified and isolated from lichens $C$. islandica and $C$. aculeata. It was shown that this substance exhibits antimicrobial activity against E. coli, B. subtilis, P. aeruginosa, L. monocytogenes [27] and antiproliferative activity towards three human cancer lines (MCF-7, HeLa and HCT-116), while did not exhibit free radical scavenging activity [42]. How are tested extracts of $C$. aculeata showed significant antioxidant activity which may be the result of high phenolic 
Table 1. Total phenolic and total antioxidant capacity of the examined Cetraria aculeata extracts

\begin{tabular}{cccc}
\hline Lichen species & Extracts & Total phenolic $(\mathrm{mg} \mathrm{GA} / \mathrm{g})$ & Total antioxidant capacity $(\mu \mathrm{g} \mathrm{AA} / \mathrm{g})$ \\
\hline \multirow{2}{*}{ Cetraria aculeata } & Methanol & Ethyl acetate & $60.8 \pm 0.79$
\end{tabular}

Table 2. The antioxidant activity of the examined Cetraria aculeata extracts

\begin{tabular}{|c|c|c|c|c|}
\hline \multirow[b]{2}{*}{$\begin{array}{l}\text { C. aculeata extracts/ } \\
\text { standards }\end{array}$} & \multicolumn{4}{|c|}{${ }^{\mathrm{a}} \mathrm{I} \mathrm{C}_{50}(\mu \mathrm{g} / \mathrm{mL})$} \\
\hline & $\begin{array}{c}\text { DPPH scavenging } \\
\text { activity }\end{array}$ & $\begin{array}{l}\text { Inhibitory activity against } \\
\text { lipid peroxidation }\end{array}$ & $\begin{array}{l}\text { Metal chelating } \\
\text { activity }\end{array}$ & $\begin{array}{c}\text { Hydroxyl radical } \\
\text { scavenging activity }\end{array}$ \\
\hline Methanol & $51.65 \pm 1.38$ & $45.55 \pm 0.99$ & $50.43 \pm 0.98$ & $90.1 \pm 0.47$ \\
\hline Ethyl acetate & $41.4 \pm 0.94$ & $38.55 \pm 0.76$ & $40.55 \pm 0.93$ & $79.4 \pm 0.65$ \\
\hline Gallic acid & $3.79 \pm 0.69$ & $255.43 \pm 11.68$ & $=$ & $59.14 \pm 1.10$ \\
\hline Ascorbic acid & $6.05 \pm 0.34$ & $>1000$ & - & $160.55 \pm 2.31$ \\
\hline $\mathrm{BHT}^{-}$ & $15.61 \pm 1.26$ & $1.00 \pm 0.23$ & - & $33.92 \pm 0.79$ \\
\hline$a$-Tocopherol & - & $0.48 \pm 0.05$ & - & - \\
\hline
\end{tabular}

a $\mathrm{C} 50$ values were determined by nonlinear regression analysis. Results are mean values \pm SD from three experiments.

Table 3. $I_{50}$ values (means $\pm S D$ ) of methanol extract of $C$. aculeata compared with methanol extract of $T$. candida, using the Student's t-test

\begin{tabular}{|c|c|c|c|}
\hline$I C_{50}(\mu \mathrm{g} / \mathrm{mL})$ & $\begin{array}{l}\text { Cetraria aculeata } \\
\text { methanol extract }\end{array}$ & $\begin{array}{c}\text { Toninia candida } \\
\text { methanol extract [40] }\end{array}$ & t-test \\
\hline DPPH scavenging activity & $51.65 \pm 1.38$ & $51.45 \pm 1.78$ & n.s. \\
\hline Inhibitory activity against lipid peroxidation & $45.55 \pm 0.99$ & $46.46 \pm 1.68$ & n.s. \\
\hline Metal chelating activity & $50.43 \pm 0.98$ & $41.91 \pm 0.88$ & * \\
\hline Hydroxyl radical scavenging activity & $90.1 \pm 0.47$ & $67.11 \pm 0.23$ & * \\
\hline
\end{tabular}

Data were analysed by Student's t-test. (* $p<0.05$; n. s. not significant)

content. Future research of lichen $\mathrm{C}$. aculeata can be focused to the identification and isolation of compounds on which depends the antioxidant activity of the tested extracts.

Previous studies have reported the antioxidant properties of aqueous extracts of C. islandica [43], but this is the first time to study the antioxidant activity of extracts $C$. aculeata.

These results showed that the methanol extract has a higher total phenolic content and total antioxidant capacity than the ethyl acetate extract. The high total phenolic content explains the strong antioxidant activity of $C$. aculeata assessed by the different systems. Recent study have been proved positive correlation between phenolic composition and antioxidant activity [44, 45]. Results of DPPH scavenging activity of ethyl acetate extract $(41.4 \pm 0.94 \mu \mathrm{g} / \mathrm{mL})$ shows a higher activity than methanol extract $(51.65 \pm 1.38 \mu \mathrm{g} / \mathrm{mL})$. Our study have shown that ethyl acetate extract of $\mathrm{C}$. aculeata displayed a higher scavenging activity than the activity of methanol, chloroform and petrol ether extracts of Toninia candida [40]. Both tested extracts of C. aculeata showed higher scavenging activity compared to the methanol extracts of Parmelia sulcata, Flavoparmelia caperata, Evernia prunastri and Cladonia foliacea, while the methanol extract of $C$. aculeata showed the lower scavenging activity than the methanol extract of Hypogymnia physodes [46]. Significant antioxidant activity of extract of lichen Hypogymnia physodes arises from his lichen compounds (depsides, depsidones and usnic acid), which demonstrated strong antioxidant effects [24]. Phenol compounds are very important plant constituents because their hydroxyl groups contributed to their scavenging ability [47]. The results of inhibitory activity towards lipid peroxidation demonstrated that both tested extracts exhibited significant inhibitory activity $(45.55 \pm 0.99 \mu \mathrm{g} / \mathrm{mL}$ and $38.55 \pm 0.76 \mu \mathrm{g} / \mathrm{mL}$ for methanolic and ethyl acetate extracts), respectively. The metal chelating activity of ethyl acetate extract with an IC50 value of $40.55 \pm 0.93 \mu \mathrm{g} / \mathrm{mL}$ displayed a higher chelating activity than methanol extract (IC50 values of $50.43 \pm 0.98$ $\mu \mathrm{g} / \mathrm{mL}$ ).

The ethyl acetate extract of $C$. aculeata showed stronger hydroxyl radical scavenging activity than the methanol extract of this lichen. While both tested extracts of C. aculeata showed similar hydroxyl radical scavenging activity with the examined extracts of Umbilicaria cylindrica [48] and lower scavenging activity than the examined extracts of Toninia candida [40]. The results of hydroxyl radical scavenging activity are significant and suggest that the methanol and ethyl acetate extracts of $\mathrm{C}$. aculeata acting as primary antioxidants. The tested extracts of $C$. aculeata showed stronger antioxidant activity than the many other species of lichens [38].

Table 3 showed the IC50 values (means \pm SD) of the methanol extract of $\mathrm{C}$. aculeata compared with the methanol extract of Toninia candida [40]. Statistical analysis IC50 values of the antioxidant potential of the methanol extracts of $C$. aculeata and T. candida [40] showed the existence of statistical significance in the metal chelating and hydroxyl radical scavenging activities.

\section{CONCLUSION}

In conclusion, the results of our study showed that the tested extracts of $\mathrm{C}$. aculeata demonstrated antioxidant activity. These results indicate the application of this lichen as source of natural antioxidants that could be 
used as a possible food supplement, in the pharmaceutical industry and in the treatment of various diseases. The obtained results represent a good basis for a more detailed phytochemical examination of $\mathrm{C}$. aculeata. Future research can be focused on the identification and isolation of the active components from $C$. aculeata and examination of their biological activities.

\section{ACKNOWLEDGEMENTS}

This work was funded by the grants given by the Ministry of Education and Science of the Republic of Serbia (grant no. 5251) and Junior Project (No. 2011/05) given by the Faculty of Medical sciences, University of Kragujevac.

\section{REFERENCES}

1. Halliwell B. How to characterize an antioxidant: an update. Biochem Soc Symp. 1995; 61:73-101.

2. Sato M, Ramarathnam N, Suzuki Y, Ohkubo T, Takeuchi M, Ochi H. Varietal differences in the phenolic content and superoxide radical scavenging potential of wines from different sources. J Agric Food Chem. 1996; 44(1):37-41.

3. Squadrito GL, Pryor WA. Oxidative chemistry of nitric oxide: the role of superoxide, peroxynitrite and carbon dioxide. Free Radic Biol Med. 1998; 25(4-5):392-403.

4. Yildirim A, Mavi A, Oktay M, Kara AA, Algur ÖF, Bilaloglu V. Comparison of antioxidant and antimicrobial activities of tilia (Tilia argentea Desf ex DC), sage (Salvia triloba L.) and black tea (Camellia sinensis) extracts. J Agric Food Chem. 2000; 48(10):50304.

5. Huda-Faujan N, Noriham A, Norrakiah AS, Babji AS. Antioxidant activity of plants methanolic extracts containing phenolic compounds. Afr J Biotechnol. 2009; 8(3):484-9.

6. Halliwell B, Gutteridge JM. Free Radical in Biology and Medicine. Oxford: Clarendon Press; 1989.

7. Halliwell B. Free radicals, antioxidants and human disease: curiosity, cause or consequence? Lancet 1994; 344(8924):721-4.

8. Davies KJ. Oxidative stress: the paradox of aerobic life. Biochem Soc Symp. 1995; 61:1-31.

9. Robinson EE, Maxwell SR, Thorpe GH. An investigation of the antioxidant activity of black tea using enhanced chemiluminescence. Free Radic Res. 1997; 26(3):291-302.

10. Sangameswaran B, Balakrishnan BR, Deshraj C, Jayakar B. In vitro antioxidant activity of roots of Thespesia lampas Dalz and Gips. Pak J Pharm Sci. 2009; 22(4):368-72.

11. Büyükokuroğlu ME, Gülçin I, Oktay M, Küfrevioğlu Öi. In vitro antioxidant properties of dantrolene sodium. Pharmacol Res. 2001; 44(6):491-4.

12. Ames BN, Shigenaga MK, Hagen TM. Oxidants, antioxidants, and the degenerative diseases of aging. Proc Natl Acad of Sci U S A. 1993; 90(17):7915-22.

13. Pietta P, Simonetti P, Mauri P. Antioxidant activity of selected medicinal plants. J Agric Food Chem. 1998; 46(11):4487-90.

14. Yen GC, Hsieh CL. Antioxidant activity of extracts from Du-Zhong (Eucommia ulmoides) toward various lipid peroxidation in vitro. J Agric Food Chem. 1998; 46(10):3952-57.

15. Wichi HP. Enhanced tumor development by butylated hydroxytoluene (BHT) in the liver, lung and gastro-intestinal tract. Food Chem Toxicol. 1986; 24(10-11):1127-30.

16. Grice HC. Safety evaluation of butylated hydroxyanisole from the perspective of effect on forestomach and oesophageal squamous epithelium. Food Chem Toxicol. 1988; 26(8):717-23.

17. Souri E, Amin G, Farsam H, Jalalizadeh H, Barezi S. Screening of thirteen medicinal plant extracts for antioxidant activity. Iran J Pharm Res. 2008; 7(2):149-54.

18. Rechner AR, Kuhnle G, Bremmer P, Hubbard GP, Moore KP, Rice-Evans CA. The metabolic fate of dietary polyphenols in humans. Free Radic Biol and Med. 2002; 33(2):220-35.

19. Zhang WM, Li B, Han L, Zhang HD. Antioxidant activities of extracts from areca (Areca catectu L.) flower, husk and seed. Afr J Biotechnol. 2009; 8(16):3887-92.

20. Eisenreich W, Knispel N, Beck A. Advanced methods for the study of the chemistry and the metabolism of lichens. Phytochem Rev. 2011; 10(3):445-56.

21. Devi GK. Anantharaman P, Kathiresan K, Balasubramanian T. Antimicrobial activities of the lichen Roccella belangeriana (Awasthi) from mangroves of Gulf of Mannar. Indian J Geomarine Sci. 2011; 40(3):449-53.

22. Shukla V, Joshi GP, Rawat MSM. Lichens as a potential natural source of bioactive compounds: a review. Phytochem Rev. 2010; 9(2):303-14. 
23. Manojlović N, Ranković B, Kosanić M, Vasiljević P, Stanojković T. Chemical composition of three Parmelia lichens and antioxidant, antimicrobial and cytotoxic activities of some their major metabolites. Phytomedicine 2012; $19(13): 1166-72$.

24. Ranković B, Kosanić M, Manojlović N, Rančić A, Stanojković T. Chemical composition of Hypogymnia physodes lichen and biological activities of some its major metabolites. Med Chem Res. 2014; 23(1):408-16.

25. Kosanić M, Ranković B, Stanojković T, Rančić A, Manojlović N. Cladonia lichens and their major metabolites as possible natural antioxidant, antimicrobial and anticancer agents. LWT - Food Sci Technol. 2014; 59(1):518-25.

26. Hidalgo ME, Fernández E, Quilhot W, Lissi E. Antioxidant activity of depsides and depsidones. Phytochemistry 1994; 37(6):15857.

27. Türk AÖ, Yilmaz M, Kivanç M, Türk H. The Antimicrobial activity of extracts of the lichen Cetraria aculeata and its protolichesterinic acid constituent. Z Naturforsch C. 2003; 58(11-12):850-4.

28. Zeytinoglu H, Incesu Z, Tuylu BA, Turk AO, Barutca B. Determination of genotoxic, antigenotoxic and cytotoxic potential of the extract from lichen Cetraria aculeata (Schreb.) Fr. in vitro. Phytother Res. 2008; 22(1):118-23.

29. Singleton V, Orthofer R, Lamuela-Raventos RM. Analysis of total phenols and other oxidation substrates and antioxidants by means of folin-ciocalteu reagent. Methods Enzymol. 1999; 299:152-78.

30. Prieto $P$, Pineda M, Aguilar M. Spectrophotometric quantitation of antioxidant capacity through the formation of a phosphomolybdenum complex: specific application to the determination of vitamin E. Anal Biochem. $1999 ; 269(2): 337-41$.

31. Takao T, Kitatani F, Watanabe N, Yagi A, Sakata K. A simple screening method for antioxidants and isolation of several antioxidants produced by marine bacteria from fish and shellfish. Biosci Biotech Biochem. 1994; 58(10):1780-83.

32. Kumarasamy Y, Byres M, Cox PJ, Jaspars M, Nahar L, Sarker SD. Screening seeds of some Scottish plants for free radical scavenging activity. Phytother Res. 2007; 21(7):615-21.

33. Hsu CK, Chiang BH, Chen YS, Yang JH, Liu CL. Improving the antioxidant activity of buckwheat (Fagopyrum tataricm Gaertn) sprout with trace element water. Food Chem. 2008; 108(2):633-41.

34. Carter P. Spectrophotometric determination of serum iron at the submicrogram level with a new reagent (ferrozine). Anal Biochem. 1971; 40(2):450-58.

35. Yan LY, Teng LT, Jhi TJ. Antioxidant properties of Guava fruits: comparison with some local fruits. Sunway Acad J. 2006; 3:9-20.

36. Hinneburg I, Dorman HJD, Hiltunen R. Antioxidant activities of extracts from selected culinary herbs and spices. Food Chem. 2006; 97(1):122-29.

37. Behera BC, Verma N, Sonone A, Makhija U. Determination of antioxidative potential of lichen Usnea ghattensis in vitro. LWT Food Sci Technol. 2006; 39(1):80-5.

38. Gulluce M, Aslan A, Sokmen M, Sahin F, Adiguzel A, Agar G, et al. Screening the antioxidant and antimicrobial properties of the lichens Parmelia saxatilis, Platismatia glauca, Ramalina pollinaria, Ramalina polymorpha and Umbilicaria nylanderiana. Phytomedicine 2006; 13(7):515-21.

39. Ranković B, Ranković D, Kosanić M, Marić D. Antioxidant and antimicrobial properties of the lichens Anaptychya ciliaris, Nephroma parile, Ochrolechia tartarea and Parmelia centrifuga. Cent Eur J Biol. 2010; 5(5):649-55.

40. Manojlović NT, Vasiljević PJ, Mašković PZ. Chemical composition and antioxidant activity of lichen Toninia candida. Rev Bras Farmacogn. 2012; 22(2):291-98.

41. Marković ZS, Manojlović NT. Analytical characterization of lichexanthone in lichen: HPLC, UV spectroscopic, and DFT analysis of lichexanthone extracted from Laurera benguelensis (Mull. Arg.) Zahlbr. Monatsh Chem. 2010; 141(9):945-52.

42. Brisdelli F, Perilli M, Sellitri D, Piovano M, Garbarino JA, Nicoletti M, et al. Cytotoxic activity and antioxidant capacity of purified lichen metabolites: an in vitro study. Phytother Res. 2013; 27(3):431-7.

43. Gülçin I, Oktay M, Küfrevioğlu Öi, Aslan A. Determination of antioxidant activity of lichen Cetraria islandica (L) Ach. J Ethnopharmacol. 2002; 79(3):325-9.

44. Katalinic V, Milos M, Kulisic T, Jukic M. Screening of 70 medicinal plant extracts for antioxidant capacity and total phenols. Food Chem. 2006; 94(4):550-7.

45. Behera BC, Verma N, Sonone A, Makhija U. Optimization of culture conditions for lichen Usnea ghattensis G. awasthi to increase biomass and antioxidant metabolite production. Food Technol Biotechnol. 2009; 47(1):7-12.

46. Mitrović T, Stamenković S, Cvetković V, Tošić S, Stanković M, Radojević I, et al. Antioxidant, antimicrobial and antiproliferative activities of five lichen species. Int J Mol Sci. 2011; 12(8):5428-48.

47. Hatano T, Edamatsu R, Hiramatsu M, Mori A, Fujita Y, Yasuhara T, et al. Effect of interaction of tannins with co-existing substances. VI. Effects of tannins and related polyphenols on superoxide anion radical and on 1,1-diphenyl-2-picrylhydrazyl radical. Chem Pharm Bull. 1989; 37(8):2016-21.

48. Manojlović NT, Vasiljević PJ, Mašković PZ, Jušković M. Bogdanović-Dušanović G. Chemical Composition, Antioxidant, and Antimicrobial Activities of Lichen Umbilicaria cylindrica (L.) Delise (Umbilicariaceae). Evid Based Complement Alternat Med. 2012; 1-8. 


\section{SRPSKI}

\section{ANTIOKSIDATIVNA AKTIVNOST LIŠAJA CETRARIA ACULEATA}

Tomović J. ${ }^{1}$, Rančić A. ${ }^{1}$, Vasiljević $\mathrm{P} .{ }^{2}$, Mašković $\mathrm{P} .{ }^{3}$, Živanović $\mathrm{S} .{ }^{4}$, Manojlović N. ${ }^{1}$, Sovrlić M. ${ }^{1}$

${ }^{1}$ Fakultet medicinskih nauka, Univerzitet u Kragujevcu, Kragujevac, Srbija

${ }^{2}$ Prirodno-matematički fakultet, Univerzitet u Nišu, Niš, Srbija

${ }^{3}$ Agronomski fakultet, Univerzitet u Kragujevcu, Čačak, Srbija

${ }^{4}$ Medicinski fakultet Univerziteta u Nišu, Niš, Serbia

\section{SAŽETAK}

Cilj ovog istraživanja je da se odrede antioksidantna svojstva lišaja Cetraria aculeata koji raste u Srbiji. Antioksidativna aktivnost metanolnog i etilacetatnog ekstrakta lišaja je testirana različitim metodama: određivanje ukupnog fenolnog sadržaja, određivanje ukupnog antioksidativnog kapaciteta, aktivnosti slobodnih radikala DPPH, inhibitorna aktivnost prema lipidnoj peroksidaciji, sposobnost vezivanja fero jona i aktivnost hidroksil radikala. Ekstrakti lišaja C. aculeata pokazali su značajnu antioksidativnu aktivnost. Metanolni ekstrakt je pokazao veće vrednosti za ukupne fenole i ukupni antioksidativni kapacitet u odnosu na etilacetatni ekstrakt, dok je etilacetatni ekstrakt pokazao bolje rezultate za aktivnosti DPPH radikala, inhibitornu aktivnost prema lipidnoj peroksidaciji, sposobnost $\mathrm{i}$ aktivnosti hidroksil radikala nego metanolni ekstrakt. Ovo je prvi prikaz antioksidativnih svojstava vrste Cetraria aculeata. Rezultati antioksidativne aktivnosti ukazuju na primenu ovog lišaja kao izvora prirodnih antioksidanata koji se mogu koristiti kao mogući dodatak ishrani, u farmaceutskoj industriji i u lečenju različitih bolesti.

Ključne reči: ROS, antioksidativna aktivnost, lišaj, Cetraria aculeata. 